\title{
The Effect of Parenting Style on Intrapersonal Intelligence of Pre-School Age Children
}

\author{
Kholifah* \\ Universitas PGRI Ronggolawe Tuban, Jalan Manunggal 61 Tuban \\ Siti Marliah \\ Universitas PGRI Ronggolawe Tuban, Jalan Manunggal 61 Tuban
}

\begin{abstract}
In general, people still think that success in life is determined by merely intellectual intelligence and ignores the role of other intelligences including intrapersonal intelligence. A person's ability to understand, adapt, and determine the best for oneself is parts os intrapersonal intelligence. This intelligence must be grown properly so that children can realize their existence and make the right choices based on that understanding. Parents through the applied parenting have an important role in their children's intrapersonal intelligence. The formulation of the problem is whether there is an effect of parenting on the intrapersonal intelligence of pre-school aged children at TKIT AL-Uswah Tuban for the 2020/2021 academic year. The purpose of this study is to describe the effect of parenting on the intrapersonal intelligence of pre-school age children at TKIT Al-Uswah Tuban for the academic year 2020/2021. The Kendall's Tau correlation test with the SPSS program was applied as a correlational quantitative research methodology, random sampling, questionnaire and documentation data collection methods, as well as hypothesis testing analysis. The results of data analysis reveal that the Kendall's Tau test value is 0.593 with a significance level of 0.000 or less than 0.05 so that the null hypothesis is rejected and the research hypothesis is accepted, it means that there is a close relationship between parenting patterns and intrapersonal intelligence in pre-school age children.
\end{abstract}

Keywords: Parenting style, Intrapersonal intelligence

DOI: $10.7176 / \mathrm{JEP} / 13-3-06$

Publication date: January $31^{\text {st }} 2022$

\section{Introduction}

Pre-age school children according to the Law of the Republic of Indonesia Number 20 of 2003 (UU RI Nomor 20 Th 2003) Chapter I Article 1 Point 14 concerning the National Education System states that early childhood education is a coaching effort aimed at children from birth to the age of 6 years which is carried out through the provision of educational stimuli to help growth. and physical and spiritual development so that children have readiness to enter further education.

According to the law, article 28 which concern on Early Childhood Education states about, 1) Early Childhood Education is held before basic education; 2) Early Childhood Education can be carried out through formal, nonformal and/or informal education programme ; 3) Early Childhood Education through formal education programme: Kindergarten, Raudhatul Athfal (Islamic Kindergarten), or other equivalent forms; 4) Early Childhood Education through non-formal education programme: KB TPA, or other equivalent forms; 5) Early Childhood Education through informal education programme: family or education organized by the environment, and 6) Provisions for Early Childhood Education as stated in paragraphs 1,2,3,4, are further regulated by government regulations.

Furthermore, in Article 28 paragraph 1, early childhood education is held for children from birth to the age of 6 years and is not a prerequisite for attending basic education. Montessori in Seldin (2007: 5) states that the age range from birth to 6 years, children experience the golden age, which is a period when children begin to be sensitive or sensitive to receive various stimuli. Montessori in Hainstock (1999: 12) states that the sensitive period is a period of maturity of physical and psychological functions, children are ready to respond to stimulation provided by the environment. It can be concluded that this period is a very special time because it only occurs once in the course of human development. According to Jalal (2002:4-10), education for pre-school age children is the foundation of individual development which will have a major influence on the next level of education. It is at this time that the basis of all children's potential (cognitive, language, social-emotional, physical, motor, religious, moral) is laid.

The smallest institution in society is the family, the first and foremost place where children are educated. The family has a very important role and responsibility for the development of all children's potential. Family for children is a place to get life, love, and protection. There are two different individuals in one family, namely father and mother, how these individuals can unite and be called "parents". But often in reality, children's problems originate from the family environment.

In carrying out the obligation to care for children, parents need the ability to communicate and interact 
properly and appropriately. Parenting includes various attitudes and behaviors of parents towards children, which are determinants that affect children's mental development. According to psychological theory, parenting is alluded to in two theories, namely behavioral theory (behavioristic) and psychoanalytic theory. Behavioral theory considers parenting as a parent strategy in shaping or producing certain behaviors in children while the psychoanalytic theory places parenting as a constellation (order or form) of parental attitudes to children that cause an emotional experience in children (Darling \& Steinberg, 1993; Lerner, 1995). The approach of parenting concept explicitly began to be put forward by experts using a pattern dimension approach which was used to study and classify the normal variations of parenting into certain types of parenting patterns. According to Susanto (2015; 26) parenting is a pattern of interaction between children and parents during the child's care.

Parenting does not only involve how parents treat children, but also how parents educate children, guide, discipline and protect children to reach maturity in accordance with the norms prevailing in society. It was further explained that the parenting style carried out by the family includes how parents take care of young children according to their gender, take care of young person in the process of developing from a child into an adult, protect from something that hurts or harm them, educates their mind, help the children to be more mature physically and spiritually with awareness and responsibility, guiding children to be able to independent and be responsible for their lives.

There are several types of parenting styles, as stated by Lazarus (1976: 242) in Susanto (2015: 144). According to him, the types of parenting styles of parents towards their children are: a) Parental attitudes toward the child can be described as neclectful; b) Overprotective, possessive; c) Rejecting and so on . Susanto also stated (2015: 114) that in general, parenting styles are categorized into two types : positive parenting style including: a) warmth; b) receive; c) give freedom; d) independence; e) attention, and others, while the negative ones are: a) permissive; b) spoiling; c) dominate; d) overprotection; e) hostile relationship; f) strict; g) mean; h) refuse and others.

Therefore, Erna Wulan Syaodih (1999:26) in Susanto (2015: 144) formulates the ideal or positive parenting style for pre-school aged children : a) intimacy, marked by feelings of warmth, affection, closeness to each other; b) caring, characterized by caring for children with full attention, interest, and sincerity; c) freedom, defined by giving freedom to children to be able to choose, propose, express opinions without hesitation; d) independence, characterized by directing, encouraging and getting the child to do something, finally as the result, the child gradually can do something on their own ; e) discipline, the existence of rules that must be followed with all the consequences; f) realistic, oriented to the existing reality, directing children to the realities of life; g) stable emotions, parents do not show tension, anger, sadness, anxiety, quickly offended and so on.

Parents turns tricky in carrying out their obligations to take care of their children as there is no parenting educational institution, these abilities grow naturally along with the maturity. Therefore, there are several factors that influence parenting styles:

a. Internal factors, including the age of the parents, the readiness and ability of the parents to care for, and parenting style that used to be obtained by parents

b. External factors, including the family's living environment, culture, geographic location and others.

In essence, humans are mono-pluralist, that is, they must be viewed as complete human beings, who have the dimension of consciousness as individual, social, moral, and religious beings. In this study, pre-school aged children are seen from the human dimension as meaningful individual beings in the form of independence, autonomous nature (freedom) and the unique nature of each person. Based on the Law of the Republic of Indonesia (UU RI ) number 23 of 2002 article 9 paragraph 1 concerning Child Protection, it is stated that every child has the right to receive education and teaching in the context of personal development and the level of intelligence according to his interests and talents.

Living life in the era of technology must have high self-confidence, be smart, creative and skilful, especially in the future, life will be more complex than today. The impact of technology is extraordinary on human behavior and the order of life. Life is getting more and more erratic, the demands are getting tougher, so to live it requires a precise, reliable and mentally tough strategy. Parents put all their hopes on their children as future generations therefore children are prepared to become individuals who are ready to face the challenges of life. Howard Gardner (1993), is a psychologist and professor of education from Harvard University US formulated the theory of Multiple Intelligences. His research concludes that in every child there are eight types of intelligence that are ready to develop. Gardner in Antonius, Atosokhi, et al (2003: 54). The multiple intelligences in question are linguistic, logical-mathematical, naturalist, visual-spatial, kinesthetic, musical, interpersonal, and intrapersonal intelligences.

According to Gardner (1993), intrapersonal and interpersonal intelligence are categorized as personal intelligence. According to him, intrapersonal intelligence is an ability to recognize the feelings that exist within oneself, such as feelings of pleasure or feelings of sadness. Meanwhile, interpersonal intelligence is the ability to see and understand differences in the mood, temperament, motivation and desires of others. While Lazear (2000) states that intrapersonal intelligence is the ability of self-introspection that opens opportunities for self-reflection so that one is aware of all aspects of oneself, such as knowledge of one's own feelings, thought processes, self- 
reflection and a sense of one's desires. So that the core of intrapersonal intelligence is self-identity and the ability to recognize one's own strengths and weaknesses.

Armstrong (2004) argues intrapersonal intelligence as a person's ability to understand himself and he acts based on that understanding. Campbell (in Musfiroh, 2008: 93) suggests that intrapersonal intelligence is the intelligence of the inner world, intelligence that originates from a comprehensive self-understanding in order to face, plan, and solve various problems. Meanwhile, according to Susanto (2015: 238), intrapersonal intelligence is the ability to recognize one's own skills, understand oneself, and be responsible for one's own life. Umar (2010: 142) also argues about intrapersonal intelligence, namely the ability to recognize and understand oneself and dare to take responsibility for one's own actions. Children will learn something through themselves, observing what they experience and feel. Intrapersonal intelligence is an ability that can be learnt by helping individuals to relate to themselves.

Cavanagh (1982: 34) in Susanto (2015: 242) stated that intrapersonal intelligence is related to three components, namely:

1) Self-knowledge, individuals who understand themselves will be able to behave effectively and influence their psychological health conditions. On the other hand, if the individual does not understand himself, the following problems will arise: (a) alienating himself; (b) display of inadequate behavior; (c) less able to make decisions; (d) perception is tainted by the unknown part of the self; (e) avoiding situations where they may not know themselves; (f) manipulating others in relation to unknown parts of the self; (g) projecting unknown parts of oneself onto others.

2) Self-direction, is the power that gives direction to the individual in his life and full responsibility for the consequences of his behavior. On the other hand, individuals who lack self-direction will have the following problems: a) difficulty in making decisions; b) less able to face failure; c) aversion to risk; d) behave in a psychologically inappropriate way; e) identify with the confidence of others; f) generalization from one aspect to another.

3) Self-esteem is the meaning of a person's view in overall , that he is useful, capable, and virtuous. This arises as a result of how people behave in accordance with healthy values. Self-esteem motivates individuals to have a good life and protect themselves from harmful defiance.

Problems that can occur because of a lack of self-esteem, including: a) ignoring oneself and expecting others to respect him; b) showing certain behaviors in an effort to fill lost self-esteem with synthetic forms of behavior; c) view oneself without respect and love;d) over-identifying in certain roles; e) not allowing others to be psychologically intimate with him; f) ever-changing behavior in choosing friends and work partners; g) unable to forgive oneself; $h$ ) finds himself in negative ways.

(a) The child shows his own attitude, does not easily follow the behavior of others, and has a strong will to achieve something; (b) Children do not like to brag, express abilities according to their abilities, children can refuse something they do not like, but are willing to try new things, (c) Children refuse or avoid when invited to discuss issues that invite reactions from many people, do not like controversial conversations, (d) Children seem to enjoy doing their own activities, they do not ask for other people's considerations, and are able to complete activities well, (e) The child dares to try something, he seems confident, (f) The child has different opinions from the others in various matters, $(\mathrm{g})$ The child tends to remember events related to previous mistakes, $(\mathrm{h})$ The child can express his feelings , judgments, and his ideas to others, (i) Children have favorite places or personal objects and and they do not like to be disturbed (j) Children have hobbies, interests, or pleasures that are strived to be recognized and refuse to carry out activities that are not of interest.

Meanwhile, according to Suyadi (2010: 177) the characteristics of children who have intrapersonal intelligence: (1) He likes to invite friends to play (2) Happy to contemplate or think when he is alone, (3) Often expresses his ideals to others, (4) Shows high self-confidence, (5) Always plays actively, (6) Able to set playing targets, (7) He is always enthusiastic when playing, and has high motivation(8) The child is often aloof, fantasizes and thinks (9) Often shows pride toys to others and (10) When he is angry he is silent as if controlling his emotions. Whereas in general children who do not have intrapersonal intelligence tend to: 1) lack confidence, 2) lack selfcontrol, 3) less responsibility, 4) less independent, 5) do not understand themselves, and so on.

However, in general, people pay more attention to intellectual intelligence, than other intelligences, a successful person is if the person has high intellectual intelligence. Many parents consider normal things and not something special when their children are able to express their opinions, have self-confidence, are able to refuse to do something that is not in accordance with their wishes, are able to make their own choices and so on. In fact, parents often think that such a child is an unpleasant child, troublesome to parents, likes to argue, disobeys to parents and so on. Therefore, it is very important if parents realize that the pioneering success of a child's life does not only rely on high intelligence, but there are other intelligences that must be possessed, namely intrapersonal intelligence. The efforts of parents in educating their children intrapersonally is an obligation that is not easy to carry out, so parents should have enthusiasm, belief and hope. Susanto argues (2015: 302) regarding the things that parents can do are: (1) Children are taught to express their feelings in personal journals, (2) Talk about their 
interests and circumstances, (3) Provide opportunities to draw themselves from the child's point of view, (4) Imagine themselves in the future, (5) Encourage him to imagine being a character in the story. Parents make these efforts in the hope that children can have abilities related to self-knowledge (they understand their weaknesses and strengths), the ability to act adaptively based on self-experience, be able to reflect, have self-balance, and high awareness of opinion. or put forward ideas. In this case, for pre-school age children, the efforts made are by teaching children to (1) recognize themselves physically, (2) recognize their favorite colors, (3) recognize their favorite fruits and pets, (4) recognize their own aspirations, (5) Recognize and express feelings (6) Motivate himself. To carry out the things described previously, parents can carry out these efforts according to the characteristics of the child

\section{Research Methodology}

This type of research is quantitative correlational. The population is all students of TKITAl-Uswah Tuban, where the sample is taken by random sampling for 38 students. Sources of data include primary data of parents and students, secondary data are principals and teachers. Data collection using the direct questionnaire method, means that parents fill out a questionnaire about the applied parenting, and an indirect questionnaire about intrapersonal intelligence whose targets are children, but the parents who fill out the questionnaire for each student because the child cannot read and write. The documentation method is carried out to obtain data sourced from documents in the school. The data analysis using the Kendall's Tau formula with the help of the SPSS program.

\section{Results and Discussion}

The conclusion of the study entitled "The Influence of Parenting Style on Intrapersonal Intelligence of Pre-school Aged Children" shows that parenting styles affect children's intrapersonal intelligence at TKIT Al-Uswah Tuban in 2020/2021. The results of data analysis state that the Kendall's Tau test value is 0.593 with a significance level of 0.000 or less than 0.05 so that the null hypothesis is rejected and the research hypothesis accepted is that there is a relationship between parenting style and intrapersonal intelligence in pre-school aged children.

Parents as absolute power holders have full responsibility for the survival of their children's lives. Basically, parents in caring for their children already have a certain way or pattern of interaction. Parenting is a factor that cannot be ignored, because it affects the growth and development of children. According to the psychoanalytic approach, good parenting really determines a child's personality, because a person's personality is influenced by various aspects that have been formed in the first years of a child's life. Baumrind in Yusuf (2006: 51) reveals how much influence "parenting style" has on children's behavior. If parents apply authoritarian parenting, their children: a) Easily irritated, b) Cowardly, c) Moody, d) Unhappy, e) Easily influenced, f) Easily stressed, g) Do not have a clear future direction, $h$ ) Hostile. If parents apply authoritative parenting, their children will: a) be friendly, b) have self-confidence, c) be able to control themselves, d) be polite, e) want to work together, f) have a high curiosity, g) Have a clear direction or purpose in life, h) Oriented to achievement. If parents apply Permissive parenting, their children: a) Be impulsive and aggressive b) Like to rebel, c) Lack self-confidence and self-control, d) Like to dominate, e) Unclear direction in life, f) Low achievement.

Various stimuli from the environment can trigger the development of multiple intelligences, which are recommended in building the life success of the millennial generation. It must be understood that intelligent people are not only described in terms of academics, according to Lazear (2000) the characteristics of intelligent people are:

a) Those who can solve the problems they face in their lives, b) Those who can face life's challenges creatively, c) Those who can produce things that are beneficial to themselves and others. According to Suyadi (2010: 178) children who have dominant intrapersonal intelligence have the ability to find ways or solutions to express their feelings and thoughts appropriately. If he has a complicated problem, he is also able to motivate himself to get up immediately and push himself to achieve his goals or targets. Therefore, it must be considered, what kind of stimulation or what kind of care is appropriate to apply and have a positive effect on the growth and development of intrapersonal intelligence. If the child has intrapersonal intelligence, then he can realize his rights appropriately When parents guide and direct their children to be aware of their existence, keep in mind that every child has a different capacity for intrapersonal intelligence, this is certainly influenced by indoginal or exogenous factors. The parenting style of parents as an exogenous factor clearly determines its role. How "intensive" and "accurate" the parenting applied by parents is, that will affect the success or failure of the child to have intrapersonal intelligence. It is very unwise, if parents force their children to always follow their wishes without paying attention to the "want" and "capacity" of the child. Parents should pay attention to the existency of their children, and how their character, because these things are extremely significant in providing guidance and direction when interacting in the parenting process. It should be understood that psychological strength is largely determined by how far people know and relate to themselves and the strength to face various challenges in their entire life, including the various problems they face.Please be a reminder for parents and teachers, according to Gardner in Anita Yus (2010: 10) that essentially every child is intelligent, this view opposes that intelligence is only seen from the IQ factor. 


\section{References}

Amstrong, T. 2004. Menerapkan multiple intellegences di sekolah (alih bahasa Yudhi Murtanto) Bandung: Penerbit Kaifa PT Mizan Pustaka.jurnal (akses 16-1-21)

Anita Yus. 2011. Model Pendidikan Anak Usia Dini. Jakarta: Kencana.

Antonius, A., Antonina. \& Yohanes Babari. 2003. Relasi Dengan Diri Sendiri. Jakarta: Gramedia.

Baumrind, D. 1966. Effects of authoritative parental control on child behavior. Child Development, 46(4), 22(2), 345-347. Doi: 10.207/1126611.jurnal (akses 11-2-21)

Cavanagh, Michael. 1982. The Counseling Experience. California: Brooks/Cole Publishing Co.

Darling, N., \& Steinberg, L. 1993. Parenting Style as context:An integrative model. Psychological Bulletin, 113(3) 487-496. doi: 10.1037/0033-2909.113.3.487.

Departemen Pendidikan Nasional. 2003. Undang-Undang Sistem Pendidikan Nasional (UU RI No 20 Tahun2003) dan Peraturan Pelaksanaannya. Jakarta: Departemen Pendidikan Nasional.

Departemen Sosial. 2002. Undang-Undang RI No. 23 Tahun2002 Tentang Perlindungan Anak. Jakarta: Direktorat Pelayanan Sosial Anak.

Gardner, Howard. 1993. Multiple Intelegences: The Theory in Practice. New York: Basis Books, Inc.

Hainstock, Elizabeth.1999. Metode Pengajaran Montessori untuk Anak Prasekolah. Jakarta: Pustaka Delaprastasa.

Hurlock. 1974. Personality Development.New York: McGraw-Hill Publishing Co Ltd.

Indar, Agnes, dkk. 2019. Mengembangkan Konsep Dan Pengukuran Pengasuhan dalam Perspektif Kontekstual

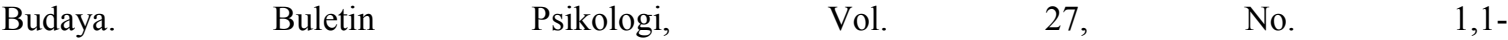
14.DOI:10.22146/bulletinpsikologi.41079.https:jurnal.ugm.ac.id/buletinpsikologi.

Jalal, Fasli. 2002. Pendidikan Anak Usia Dini: Pendidikan yang mendasar. Buletin PADU, Edisi Perdana.

Lazarus, Richard. 1976. Pattern of Adjustment. Tokyo: Mcgraw-Hill Kogakusha.

Lazear, D. 2000. Pathways of learning teaching students and parents about multiple intelegences. Arizona Tucson: Zephyr Press

Lerner, R. M. 1995. American's Youth in crisis: Challenges \& optin for programs \& policies.doi:10.4135/9781483327167.

Musfiroh, Tadkirotun. 2008. Cerdas Melalui Bermain. Jakarta: PT. Gramedia.

Nurani Yuliati. 2012. Konsep Dasar Pendidikan Anak Usia Dini. Jakarta, PT Indeks ???

Nithy Theva, 2017. Bijaksana Mengasuh dan Menumbuhkembangkan Anak. Jakarta, Indeks.???

Seldin, Tim. 2007. How to raise an Amazing Child:the Montessori way to bring up caring, confident children. Dorling Kindersley, Penguin Company.

Sugiyono. 2013. Metode Penelitian Kuantitatif Kualitatif dan R\&D. Bandung: CV Alfabet

Susanto, Ahmad. 2015. Bimbingan Dan Konseling Di TK, Jakarta, Penerbit Prenadamedia.

Suyadi. 2010. Psikologi Belajar Penidikan Usia Dini. Yogyakarta: PT Putaka Intan Madani.

Syaodih S, Ernawulan. 1999. "Peranan Bimbingan Guru, Pengasuhan Orang Tua, dan Interaksi Teman Sebaya terhadap perkembangan Perilaku Sosial Anak". Tesis. Bandung: SPs UPI Bandung. Bandung: FIP-IKIP.

Umar, Asep Fahrudin. (2010). Sukses menjadi Guru TK-PAUD. Jogjakarta: Bening.jurnal(akses 10-10-20) Undang-undang Nomor 20 Tahun 2003 Tentang Sistim Pendidikan Nasional \& Undang-undang Nomor 14 Tahun 2005 tentang Guru dan Dosen. Jakarta: Visimedia

Yusuf, Syamsu. 2006. Psikologi Perkembangan anak dan Remaja. Bandung: PT. Remaja Rosdakarya.Notes 